\title{
NEW THERAPIES FOR HEPATITIS C VIRUS
}

\section{Hari Polenakovik, MD FACP FIDSA}

Associate Professor of Medicine, Wright State University Boonshoft School of Medicine Infectious Diseases Physician, Medical Director of Epidemiology, Miami Valley Hospital Associate Director, Adult Cystic Fibrosis Program, Dayton Children's Hospital

Corresponding Author: Hari Polenakovik, MD FACP FIDSA, 128 East Apple Street, Weber CHE 2nd floor, Dayton,Ohio 45409, USA; Office: +1-937-208-2873; Fax: +1-937-208-2621; E-mail: Hari.polenakovik@wright.edu

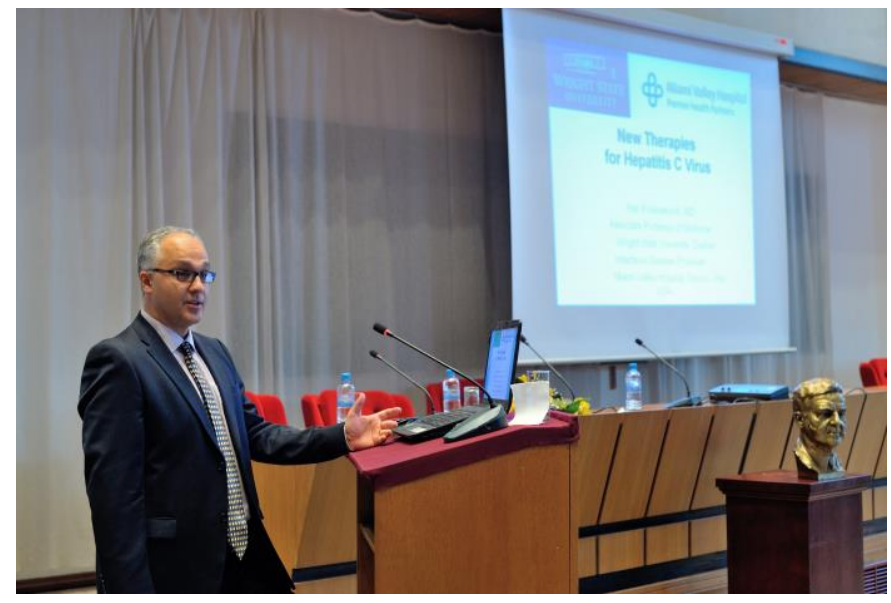

\begin{abstract}
Hepatitis $\mathrm{C}$ virus (HCV), the major etiologic agent of "non-A, non-B hepatitis" was discovered 26 years ago. Even before its discovery, interferon- $\alpha$ (IFN) was already being used for treatment of this infection. The next two decades saw a series of incremental improvements of the IFN therapies by extending the duration of therapy, using IFN in combination with oral ribavirin, using pegylated IFN with ribavirin, and most recently adding oral compounds that inhibit the HCV replication (directly acting antivirals - DAAs) to that regimen. DAAs target multiple steps in the HCV life cycle and are now used in combination to treat HCV infection without the need of IFN. These IFN-free, oral DAAs regimens are highly efficacious, have minimal toxicity and are given for short duration. Approved DAAs can cure more then $90 \%$ of persons with chronic HCV infection, thereby reducing the risk of death from cirrhosis and hepatocellular carcinoma. However, these drugs are very expensive, and currently their exorbitant cost significantly restricts the access to this therapy for many HCV infected patients.
\end{abstract}

Key words: Hepatitis C, Treatment, Directly Acting Antivirals

\section{Introduction}

$\mathrm{HCV}$ is a blood-borne virus, capable of causing both acute and chronic hepatitis, ranging in severity from a mild self-limiting illness to a serious, lifelong illness. [1-5] World Health Organization (WHO) estimates that 130 to 150 million people globally have chronic hepatitis $\mathrm{C}$ infection (CHC). [1] While HCV is found worldwide, certain countries have extreme $\mathrm{HCV}$ disease burden (e.g., Egypt). Africa and Central and East Asia have the highest prevalence of $\mathrm{CHC}$, where inadequate sterilization of re-usable medical equipment and transfusion of unscreened blood or blood products have been the predominant modes of HCV transmission. [1, 2] In developed countries, CHC is concentrated in certain populations such as injection drug users (IDA). [1-3] 
HCV causes both acute and chronic infection. [1-5] Patients with acute HCV infection are often asymptomatic or have nonspecific symptoms (fatigue, abdominal pain, nausea) that frequently are not recognized as being associated with acute HCV infection. [2, 3] A small proportion $(<25 \%)$ of patients with acute $\mathrm{HCV}$ infection will develop jaundice, however acute liver failure is very rare $(<1 \%)$. [2-3] Acute $\mathrm{HCV}$ infection is usually self-limited illness. About $20-50 \%$ of infected persons spontaneously clear the virus within 6 months of infection without any treatment. [1-5] The remainning 50-80\% of persons will develop CHC. Many of them lack specific symptoms, and are unaware of the presence of this infection. People with $\mathrm{CHC}$ are at increased risk for impairments in quality of life, extra-hepatic complications (e.g., mixed cryoglobulinemia, membranoproliferative glomerulonephritis, porphyria cutanea tarda, etc.), and liver-related morbidity and mortality. [1-5] $\mathrm{CHC}$ causes cirrhosis, liver failure and heaptocellular carcinoma and is currently the most common reason for liver transplantation in many countries of the world. [1-5] According to WHO, $\mathrm{HCV}$ is responsible for approximately 500000 deaths each year globally. [1, 2] HCV infection is curable and complications can be prevented. Until 2 years ago, the treatment of HCV was suboptimal, but it changed dramatically with the introduction of directly acting antivirals (DAAs). This review focuses on the approved DAAs and the current $\mathrm{HCV}$ treatment recommendations.

\section{Virology and HCV life cycle}

$\mathrm{HCV}$ is a small (55 $\mathrm{nm}$ in diameter), roughly spherical ribonucleic acid (RNA) virus in the genus Hepacivirus of the Flaviviridae family. [2-5] There are six major viral HCV genotypes (or clades), numbered 1 to 6 . The genotypes are divided into subtypes; however, this subdivision is of clinical importance only for genotype 1 (subtypes $1 \mathrm{a}$ and $1 \mathrm{~b}$ ). [2-5] In the United States and in Europe, genotype 1 is the most common (70 to 80 percent), followed by genotypes 2 and 3. Different genotypes may predominate in other countries (e.g., genotype 4 is the major genotype in Egypt). [1-5]

The genome of $\mathrm{HCV}$ is a positive-sense, single-stranded RNA molecule approximately $9.6 \mathrm{~kb}$ in length, which contains a large open reading frame (ORF) that encodes a single large polyprotein ( $\approx 3010$ amino acids). [2] This polyprotein is processed by host-cellular and viral proteases into 10 proteins. [2] There are 3 "structural" proteins [the nucleocapsid protein, core (C), and two envelope proteins (E1 and E2)], 2 proteins that are essential for virion production but not required for viral RNA replication (p7 and NS2); and 5 nonstructural (NS) proteins that form the viral RNA replicase complex (NS3, NS4A, NS4B, NS5A, and NS5B) (Figure 1: $\mathrm{HCV}$ life cycle). [2] These non-structural proteins are the main targets for the directly acting antiviral (DAAs) agents (see below). [2, 4, 5] Development of cell culture based HCV replicon systems in 2005 allowed for detailed view of the HCV life cycle and greatly facilitated the antiviral drug discovery (Figure 1). [2, 4, 5]

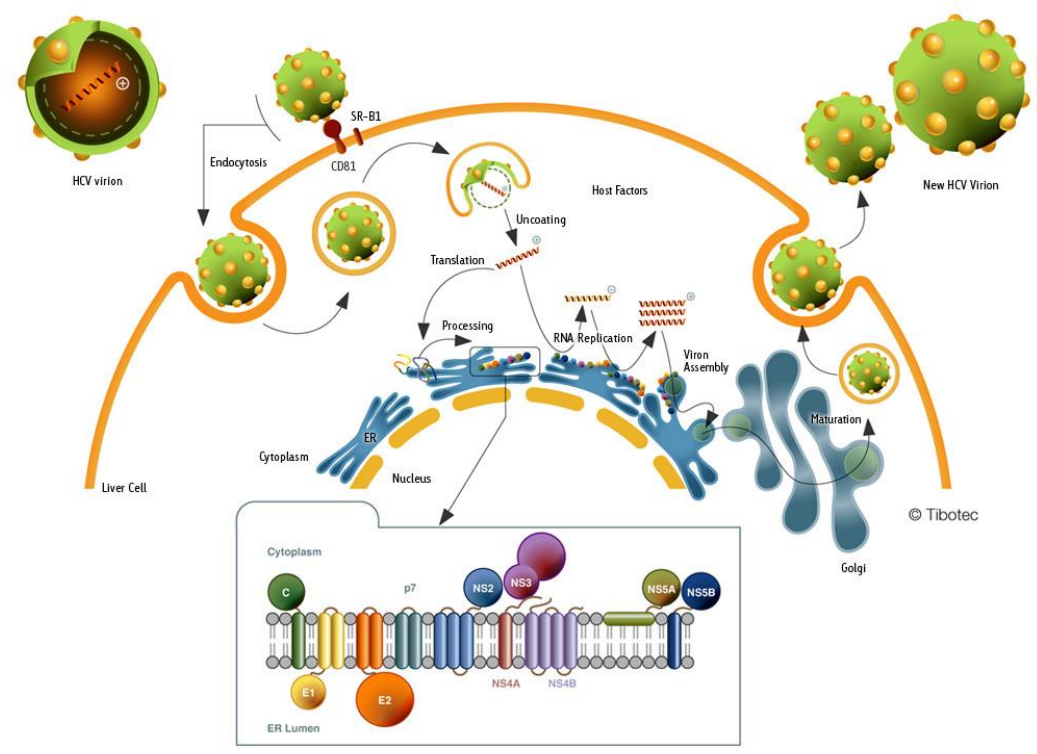

Figure 1-HCV Life cycle 
The virus enters the cell through interaction with many cell surface receptor molecules (such as CD81, the LDL receptor, the EGF receptor, the tight junction proteins claudin-1, etc.). $[2,4,5]$ Following the viral entry into the cell, the RNA is released into the cytoplasm, where it acts as messenger RNA directing the translation of the viral polyprotein. Because $\mathrm{HCV}$ does not replicate through DNA intermediary, it does not integrate into the host genome. The $\mathrm{HCV}$ polyprotein undergoes a series of translational and posttranslational proteolytic cleavages. The HCV replicase complex (composed of NS3, NS4A, NS4B, NS5A, and NS5B) forms "membranous web" and directs the synthesis of a negative-strand copy of the RNA. This RNA then serves as a template for the subsequent synthesis of multiple copies of the positive-strand genomic RNA. The RNA is packaged into new viral particles, which are then released from the host cell. The liver is the primary source of virus present in blood, with minority of virus replicating within peripheral mononuclear cells. HCV replicates at a very high rate; approximately $10^{12}$ virions are produced each day in a chronically infected person, which is 10 - to 100 -fold higher then in HIV infection. The high level of virion turnover together with the absence of proofreading by the NS5B RNA dependent RNA polymerase (RdRp) lead to evolution of multiple variants ("quasi-species") in an infected individual. [2]

\section{Treatment for hepatitis $\mathbf{C}$}

The goal of HCV treatment is eradication of the virus from the host. [2-5] This is known as a virological cure. Sustained virological response (SVR) is a surrogate for virologic cure. SVR is defined as undetectable HCV RNA in blood 12 weeks or more after treatment has finished. [2-5] An SVR prevents the develop- ment of cirrhosis and other HCV related complications. [2-5] In patients who already have cirrhosis, an SVR reduces the risks of decompensated cirrhosis and hepatocellular carcinoma, and death, and may eliminate the need for liver transplantation. [2-5]

Current treatment of $\mathrm{CHC}$ is rapidly evolving. [2-5] For the past decade, the standard of care for treatment of $\mathrm{CHC}$ had been a combination of subcutaneously-injected pegylated interferon (peg-IFN) and ribavirin administered for 24 (genotypes 2 and 3) or 48 weeks (genotype 1). [2-6] This combination produces SVR in $40-50 \% \mathrm{HCV}$ genotype 1 infected patients and 60-70\% in genotypes 2 and 3. [2-6] Addition of the first-wave first-generation of $\mathrm{HCV}$ protease inhibitors (telaprevir and boceprevir) to peg-IFN and ribavirin increases SVR to 60$75 \%$ in $\mathrm{HCV}$ genotype 1 infected patients. [2, 4-7] The use of nucleotide analogue (sofosbuvir) with peg-IFN and ribavirin produces further improvement of SVR [2, 4, 5, 9].

However the widespread use of peg-IFN containing regimens has been limited by treatment-related toxicity (e.g., flu-like symptoms, malaise, psychiatric disorders, blood counts abnormalities, autoimmune disorders and injecttion site reactions). [2-9] In addition, peg-IFN and ribavirin regimens are contraindicated in the presence of decompensated cirrhosis, uncontrolled depression, and autoimmune disease. [25] These 2 factors have created a large pool of patients with $\mathrm{CHC}$ who are peg-IFN and ribavirin intolerant or ineligible. Before the approval of DAAs, these patients previously had no treatment options. [2-5] DAAs targeting multiple steps in the HCV life cycle have been developed and are used in combination to successfully treat hepatitis $\mathrm{C}$ infected persons (Table 1). [2-5] 
Table 1

Approved DAAs (and soon to be approved DAAs) at the end of 2015 (adapted from reference 4)

\begin{tabular}{|c|c|}
\hline DAA Agent Class & Agent \\
\hline \multicolumn{2}{|l|}{ NS3-4A protease inhibitors } \\
\hline \multirow[t]{2}{*}{ First-wave, first-generation } & Telaprevir (INCIVEK) \\
\hline & Boceprevir (VICTRELIS) \\
\hline \multirow[t]{3}{*}{ Second-wave, first-generation } & Simeprevir (OLYSIO) \\
\hline & Paritaprevir/ritonavir ${ }^{a}$ \\
\hline & Asunaprevir (SUNVEPRA) \\
\hline Second-generation & Grazoprevir \\
\hline $\begin{array}{l}\text { Nucleotide analogues of the HCV RNA- } \\
\text { dependent RNA polymerase }\end{array}$ & Sofosbuvir (SOVALDI) \\
\hline $\begin{array}{l}\text { Non-nucleoside inhibitors of the HCV RNA- } \\
\text { dependent RNA polymerase }\end{array}$ & Dasabuvir $^{\text {a }}$ \\
\hline \multicolumn{2}{|l|}{ NS5A inhibitors } \\
\hline \multirow[t]{3}{*}{ First-generation } & Daclatasvir (DAKLINZA) \\
\hline & Ledipasvir $^{\mathrm{b}}$ \\
\hline & Ombitasvir $^{\mathrm{a}}$ \\
\hline Second-generation & Elbasvir \\
\hline
\end{tabular}

a VIEKIRA PAK (Paritaprevir/ritonavir, ombitasvir and dasabuvir) ("3D regimen")

${ }^{\mathrm{b}}$ HARVONI (Ledipasvir/sofobuvir)

These IFN-free regimens are highly efficacious, have minimal toxicity and are given for short duration. High SVR rates are observed, even in patients with characteristics previously associated with having lower response rates: high HCV RNA levels, infection with genotype 1a, co-infection with HIV, elderly, African American, and those who failed treatment with first-wave first-generation of $\mathrm{HCV}$ protease inhibitors (telaprevir and boceprevir). [2-5] It is now clear that IFN-free regimens are the future of $\mathrm{HCV}$ treatment for the majority of patients. Our goal should be treatment of all persons with $\mathrm{CHC}$ if they wish and are ready to start treatment and are suitable candidates for treatment. $[3,5]$

The website HCV Guidance: Recommendations for Testing, Managing, and Treating Hepatitis C, from the American Association for the Study of Liver Diseases, Infectious Diseases Society of America, and International Antiviral Society-USA (AASLD/IDSA/IAS-USA http://www.hcvguidelines.org/ and the European Association for the Stydy of the Liver (EASL) $\mathrm{HCV}$ guidelines recommend treatment for all patients with chronic $\mathrm{HCV}$ infection, except for those whose life expectancy is less then 12 months due to severe co-morbidities. [3, 5] If treatment is not readily available due to cost or other factors, the highest priority (immediate treatment) should be given to $\mathrm{HCV}$ infected patients at highest risk for liver-related complications such as patients with advanced fibrosis (Metavir F3) or compensated cirrhosis (Metavir F4), liver transplant recipients, and patients with severe extrahepatic hepatitis C (mixed cryoglobulinemia, or membranoproliferative glomerulonephritis), followed by patients at higher risk for future complications including those with advanced liver fibrosis (Metavir F2), coexisting liver disease, HIV co-infection, HBV co-infection, insulin resistant diabetes mellitus, debilitating fatigue, and porphyria cutanea tarda. [3, 5]

Current treatment recommendations for treatment naïve and previously treated patients with HCV infection, by genotype, cirrhosis status are available at HCV Guidance: Recommendations for Testing, Managing, and Treating Hepatitis C AASLD/IDSA/IAS-USA, and EASL websites, and are regularly updated as new drugs are approved and new evidence about efficacy and safety of the therapies becomes available (Table 2). Clinicians should always consult these websites for most up-to-date recommendations before treating $\mathrm{HCV}$ patients. [3, 5] 
Table 2

Treatment recommendations according to HCV Guidance: Recommendations for Testing, Managing, and Treating Hepatitis C, from the American Association for the Study of Liver Diseases, Infectious Diseases Society of America, and International Antiviral Society-USA (AASLD/IDSA/IAS-USA) http://www.hcvguidelines.org

\begin{tabular}{|c|c|c|c|}
\hline $\begin{array}{l}\mathrm{HCV} \\
\text { Genotype } \\
\text { (GT) } \\
\end{array}$ & $\begin{array}{l}\text { Treatment } \\
\text { History }\end{array}$ & $\begin{array}{l}\text { Cirrhosis } \\
\text { Status }\end{array}$ & Regimen \\
\hline \multirow{8}{*}{1} & \multirow{8}{*}{ Naive } & \multirow{4}{*}{$\begin{array}{l}\text { Non- } \\
\text { cirrhotic }\end{array}$} & $\mathrm{DCV}+\mathrm{SOF}$ x 12 weeks \\
\hline & & & $\begin{array}{l}\text { LDV/SOF x } 12 \text { weeks } \\
\text { (may consider } 8 \text { weeks if HCV RNA }<6 \text { million } \mathrm{IU} / \mathrm{mL} \text { ) }\end{array}$ \\
\hline & & & $\begin{array}{l}\text { PrOD x } 12 \text { weeks; } \\
\text { GT-1a: add RBV } \\
\text { GT-1b: RBV not required }\end{array}$ \\
\hline & & & SIM + SOF x 12 weeks \\
\hline & & \multirow{4}{*}{ Cirrhotic* } & $\begin{array}{l}\mathrm{DCV}+\mathrm{SOF} \text { x } 24 \text { weeks } \\
\text { (may consider adding RBV) }\end{array}$ \\
\hline & & & $\begin{array}{l}\text { LDV/SOF x } 12 \text { weeks } \\
\text { (may consider adding RBV) }\end{array}$ \\
\hline & & & $\begin{array}{l}\text { PrOD + RBV } \\
\text { (GT-1a: } 24 \text { weeks) } \\
\text { (GT-1b: } 12 \text { weeks) } \\
\end{array}$ \\
\hline & & & $\begin{array}{l}\text { SIM + SOF x } 24 \text { weeks } \\
\text { (may consider adding RBV) } \\
\text { GT- } 1 \text { a (only if no Q80K polymorphism) }\end{array}$ \\
\hline
\end{tabular}

* Cirrhotic refers to compensated cirrhotic (MELD < 15) 


\begin{tabular}{|c|c|c|c|}
\hline $\begin{array}{l}\text { HCV } \\
\text { Genotype } \\
(\mathrm{GT}) \\
\end{array}$ & Treatment History & Cirrhosis Status & Regimen \\
\hline \multirow{18}{*}{1} & \multirow{9}{*}{$\begin{array}{l}\text { Experienced (failed } \\
\text { pegIFN + RBV) }\end{array}$} & \multirow{4}{*}{ Non- cirrhotic } & DCV + SOF x 12 weeks \\
\hline & & & LDV/SOF x 12 weeks \\
\hline & & & $\begin{array}{l}\text { PrOD x } 12 \text { weeks; } \\
\text { GT-1a: add RBV } \\
\text { GT-1b: RBV not required } \\
\end{array}$ \\
\hline & & & SIM + SOF x 12 weeks \\
\hline & & \multirow{5}{*}{ Cirrhotic } & $\begin{array}{l}\mathrm{DCV}+\mathrm{SOF} \times 24 \text { weeks } \\
\text { (may consider adding RBV) }\end{array}$ \\
\hline & & & $\mathrm{LDV} / \mathrm{SOF}+\mathrm{RBV} \times 12$ weeks \\
\hline & & & LDV/SOF x 24 weeks \\
\hline & & & $\begin{array}{l}\text { PrOD + RBV } \\
\text { (GT-1a: } 24 \text { weeks) } \\
\text { (GT-1b: } 12 \text { weeks) } \\
\end{array}$ \\
\hline & & & \begin{tabular}{|l} 
SIM + SOF x 24 weeks \\
(may consider adding RBV) \\
GT-1a (only if no Q80K polymorphism) \\
\end{tabular} \\
\hline & \multirow{2}{*}{$\begin{array}{l}\text { Experienced (failed } \\
\text { SOF }+ \text { RBV } \pm \text { pegIFN) }\end{array}$} & Non- cirrhotic & LDV/SOF + RBV x 12 weeks \\
\hline & & Cirrhotic & LDV/SOF + RBV x 24 weeks \\
\hline & \multirow{5}{*}{$\begin{array}{l}\text { Experienced (failed } \\
\text { PI + pegIFN + RBV } \\
\text { or SIM + SOF) }\end{array}$} & \multirow{2}{*}{ Non- cirrhotic } & $\begin{array}{l}\mathrm{DCV}+\mathrm{SOF} \text { x } 12 \text { weeks } \\
\text { (may consider adding RBV) }\end{array}$ \\
\hline & & & $\begin{array}{l}\text { LDV/SOF x } 12 \text { weeks } \\
\text { (add RBV if prior SIM+SOF failure) }\end{array}$ \\
\hline & & \multirow{3}{*}{ Cirrhotic } & $\begin{array}{l}\text { DCV }+ \text { SOF x } 24 \text { weeks } \\
\text { (may consider adding RBV) }\end{array}$ \\
\hline & & & $\begin{array}{l}\mathrm{LDV} / \mathrm{SOF} \times 24 \text { weeks } \\
\text { (add RBV if prior SIM + SOF failure) }\end{array}$ \\
\hline & & & $\begin{array}{l}\mathrm{LDV} / \mathrm{SOF}+\mathrm{RBV} \times 12 \text { weeks } \\
\text { (do not use this combination if prior SIM+SOF } \\
\text { failure) }\end{array}$ \\
\hline & \multirow[b]{2}{*}{$\begin{array}{l}\text { Experienced (failed } \\
\text { NS5A inhibitor) }\end{array}$} & Non- cirrhotic & Deferral of treatment \\
\hline & & Cirrhotic & $\begin{array}{l}\text { Test for resistance-associated variants to NS3 } \\
\text { protease inhibitors and to NS5A inhibitors and tailor } \\
\text { treatment regimen based on the results. } \\
\text { Treat for } 24 \text { weeks. } \\
\text { Add RBV }\end{array}$ \\
\hline
\end{tabular}




\begin{tabular}{|c|c|c|c|}
\hline $\begin{array}{l}\mathrm{HCV} \\
\text { Genotype } \\
(\mathrm{GT}) \\
\end{array}$ & $\begin{array}{l}\text { Treatment } \\
\text { History }\end{array}$ & $\begin{array}{l}\text { Cirrhosis } \\
\text { Status }\end{array}$ & Regimen \\
\hline \multirow{8}{*}{2} & \multirow{4}{*}{ Naive } & \multirow{2}{*}{$\begin{array}{l}\text { Non- } \\
\text { cirrhotic }\end{array}$} & SOF + RBV x 12 weeks \\
\hline & & & $\begin{array}{l}\mathrm{DCV}+\mathrm{SOF} \times 12 \text { weeks } \\
\text { (if RBV intolerant) }\end{array}$ \\
\hline & & \multirow[b]{2}{*}{ Cirrhotic } & SOF + RBV x 16 weeks \\
\hline & & & $\begin{array}{l}\mathrm{DCV}+\mathrm{SOF} \times 16 \text { weeks } \\
\text { (if RBV intolerant) }\end{array}$ \\
\hline & \multirow{2}{*}{$\begin{array}{l}\text { Experienced } \\
\text { (failed } \\
\text { pegIFN+RBV) }\end{array}$} & \multirow{2}{*}{$\begin{array}{l}\text { Non- } \\
\text { cirrhotic or } \\
\text { Cirrhotic }\end{array}$} & $\begin{array}{l}\text { SOF + RBV x } 16 \text { weeks } \\
\text { (may consider } 24 \text { weeks) }\end{array}$ \\
\hline & & & $\begin{array}{l}\text { SOF + RBV + pegIFN x } 12 \text { weeks } \\
\text { (if IFN eligible) }\end{array}$ \\
\hline & \multirow{2}{*}{$\begin{array}{l}\text { Experienced } \\
\text { (failed } \\
\text { SOF + RBV) }\end{array}$} & \multirow{2}{*}{$\begin{array}{l}\text { Non- } \\
\text { cirrhotic or } \\
\text { Cirrhotic }\end{array}$} & $\begin{array}{l}\mathrm{DCV}+\mathrm{SOF} \times 24 \text { weeks } \\
\text { (may consider adding RBV) }\end{array}$ \\
\hline & & & $\begin{array}{l}\text { SOF + RBV + pegIFN x } 12 \text { weeks } \\
\text { (if IFN eligible) }\end{array}$ \\
\hline \multirow{10}{*}{3} & \multirow{4}{*}{ Naive } & \multirow{3}{*}{$\begin{array}{l}\text { Non- } \\
\text { cirrhotic }\end{array}$} & DCV + SOF x 12 weeks \\
\hline & & & $\begin{array}{l}\text { SOF + RBV x } 24 \text { weeks } \\
\text { (if IFN eligible) }\end{array}$ \\
\hline & & & $\begin{array}{l}\text { SOF + RBV + pegIFN x } 12 \text { weeks } \\
\text { (if IFN eligible) }\end{array}$ \\
\hline & & Cirrhotic & $\begin{array}{l}\mathrm{DCV}+\mathrm{SOF} \times 24 \text { weeks } \\
\text { (may consider adding RBV) }\end{array}$ \\
\hline & \multirow{4}{*}{$\begin{array}{l}\text { Experienced } \\
\text { (failed } \\
\text { pegIFN + RBV) }\end{array}$} & \multirow{2}{*}{$\begin{array}{l}\text { Non- } \\
\text { cirrhotic }\end{array}$} & DCV + SOF x 12 weeks \\
\hline & & & $\begin{array}{l}\text { SOF + RBV + pegIFN x } 12 \text { weeks } \\
\text { (if IFN eligible) }\end{array}$ \\
\hline & & \multirow[t]{2}{*}{ Cirrhotic } & $\mathrm{DCV}+\mathrm{SOF}+\mathrm{RBV} \times 24$ weeks \\
\hline & & & $\begin{array}{l}\text { SOF + RBV + pegIFN x } 12 \text { weeks } \\
\text { (if IFN eligible) }\end{array}$ \\
\hline & \multirow{2}{*}{$\begin{array}{l}\text { Experienced } \\
\text { (failed } \\
\text { SOF + RBV) }\end{array}$} & \multirow{2}{*}{$\begin{array}{l}\text { Non- } \\
\text { cirrhotic or } \\
\text { Cirrhotic }\end{array}$} & $\mathrm{DCV}+\mathrm{SOF}+\mathrm{RBV} \times 24$ weeks \\
\hline & & & $\begin{array}{l}\text { SOF + RBV + pegIFN x } 12 \text { weeks } \\
\text { (if IFN eligible) }\end{array}$ \\
\hline \multirow{4}{*}{4} & \multirow{4}{*}{$\begin{array}{l}\text { Naive or } \\
\text { Experienced }\end{array}$} & \multirow{4}{*}{$\begin{array}{l}\text { Non- } \\
\text { cirrhotic or } \\
\text { Cirrhotic }\end{array}$} & $\mathrm{PrO}+\mathrm{RBV}$ x 12 weeks \\
\hline & & & LDV/SOF x 12 weeks \\
\hline & & & SOF + RBV x 12 weeks \\
\hline & & & $\begin{array}{l}\text { SOF + RBV + pegIFN x } 12 \text { weeks } \\
\text { (if IFN eligible) }\end{array}$ \\
\hline \multirow{2}{*}{5 and 6} & \multirow{2}{*}{$\begin{array}{l}\text { Naive or } \\
\text { Experienced }\end{array}$} & \multirow{2}{*}{$\begin{array}{l}\text { Non- } \\
\text { cirrhotic or } \\
\text { Cirrhotic }\end{array}$} & LDV/SOF x 12 weeks \\
\hline & & & SOF + RBV + pegIFN $\times 12$ weeks (if IFN eligible) \\
\hline
\end{tabular}

Abbreviations: Peg-IFN = peginterferon; RBV = ribavirin; SOF = sofosbuvir; $\mathrm{DCV}=$ daclatasvir; $\mathrm{LDV}=$ ledipasvir; LDV/SOF = ledipasvir/sofosbuvir (Harvoni); SIM = simeprevir; PrOD = paritaprevir /ritonavir/ ombitasvir + dasabuvir (Viekira Pak); PrO = paritaprevir /ritonavir/ ombitasvir (Technivie); $\mathrm{PI}=\mathrm{HCV}$ protease inhibitor. 
Dosages:

sofosbuvir $400 \mathrm{mg}$ orally daily; daclatasivir $60 \mathrm{mg}$ orally daily; ledipasvir/sofosbuvir (90/400 mg): 1 tablet orally daily; paritaprevir/ritonavir/ombitasvir (75/50/12.5 mg): 2 tablets once daily in the morning with food + dasabuvir $250 \mathrm{mg}$ orally twice daily in the morning and in the evening with food;

simeprevir $150 \mathrm{mg}$ orally daily; ribavirin $1000 \mathrm{mg}(<75 \mathrm{~kg})$ or $1200 \mathrm{mg}(\geq 75 \mathrm{~kg})$ orally daily (in 2 divided doses) with food;

peg-IFN alfa-2a 180 mcg subcutaneously weekly or peg-IFN alfa-2b $1.5 \mathrm{mcg} / \mathrm{kg}$ subcutaneously weekly.

\section{Directly acting antivirals (DAAs)} and mechanism of action of DAAs

The HCV replication can be blocked at many steps. [2-5] Currently approved oral DAAs include NS3-4A protease inhibitors, nucleotide analogue inhibitors of the NS5B RNA-dependent RNA polymerase (RdRp), non-nucleoside inhibitors of the NS5B RdRp and inhibitors of the NS5A protein (See Table 1). [2-12]

NS3-4A protease inhibitors bind the catalytic site of the enzyme and block the proper cleavage of the viral polyproteins. [2, 4-6, 8] The first-wave, first-generation NS3-4A protease inhibitors, telaprevir and boceprevir, are only active against genotype 1 , have a low barrier to resistance, and high pill burden and numerous side effects. The second-wave, first-generation NS3-4A protease inhibitors (e.g., simeprevir, paritaprevir, and asunaprevir) have broader genotypic activity (genotypes 1, 2, and 4, but not genotype 3), lower pill burden, but still a low barrier to resistance. The second-generation NS3-4A protease inhibitors (e.g., grazoprevir not yet approved) have pangenotypic activity and an increased barrier to resistance. [4]

Nucleotide analogues mimic the naturally occurring nucleotides, and during the viral replication, they incorporate into the newly synthesized viral RNA causing chain termination. [2, 4, 5, 9] Approved nucleotide analogue sofosbuvir has pangenotypic antiviral activity and a high barrier to resistance. $[4,5,9]$

Non-nucleoside inhibitors of RdRp bind directly to the enzyme and altering its conformation and its function. [2, 4, 5] Approved non-nucleoside $\mathrm{RdRp}$ inhibitor dasabuvir is active against $\mathrm{HCV}$ genotype 1 and has a low barrier to resistance. [4]
NS5A inhibitors bind the NS5A protein and block its ability to regulate HCV replication within the replication complex and inhibit assembly and release of viral particles. [2-5, 10-12] The first-generation NS5A inhibitors (e.g., ledipasvir, daclatisvir, ombitasvir) have varied genotypic activity and a low barrier to resistance. [4, 5, 10-12] The second-generation NS5A inhibitors (e.g., elbasvir- not yet approved) have pangenotypic activity, and an increased barrier to resistance compared to first-generation agents. [4]

\section{Select DAAs}

\section{NS3-4A protease inhibitors}

This drug class is specifically designed to inhibit the NS3/4A HCV protease. These agents resemble the HCV polypeptide and, when processed by the viral protease, form a covalent bond with the catalytic NS3 serine residues, block further activity, and prevent proteolytic cleavage of the HCV polyprotein into NS4A, NS4B, NS5A, and NS5B proteins.

Telaprevir (Incivek - manufactured by Vertex Pharmaceuticals) and boceprevir (Victrelismanufactured by Merck), the first wave, first generation NS3/4A HCV protease inhibitors were significant advance in treatment of with $\mathrm{HCV}$ genotype 1 infected patients during the years 2011 to 2013. [4-8] Clinical studies in treatment-naïve patients and previously treated with peg-IFN and ribavirin showed that the addition of telaprevir or boceprevir improved SVR to 60-75\% [4-8], However, this improvement was at the cost of increased adverse effects. $[4,5,8]$ The addition of telaprevir or boceprevir to peg-IFN and ribavirin increases the risk of anemia. [6-8] Telaprevir causes occasional severe skin rashes and GI symptoms. [67] High pill burden is another problem. The recommended dosage of telaprevir is $1125 \mathrm{mg}$ (three $375 \mathrm{mg}$ tablets) twice daily and for boceprevir is $800 \mathrm{mg}$ (four $200 \mathrm{mg}$ capsules) three times daily. [6-8] Major drug-drug interactions are common as these drugs are both substrates and inhibitors of cytochrome P-450 3A4 (CYP3A4) and P-glycoprotein (P-gp). [6-8] Lastly, the rapid development of resistance with virologic breakthrough and availability of new DAAs (sofosbuvir and simeprevir) created a situation where telaprevir and boceprevir are 
very unlikely to be used in any of the future HCV therapies. [4-5]

\section{Simeprevir}

Simeprevir (Olysio - Manufacturer by Janssen Pharmaceuticals) is a second wave, first generation NS3/4A HCV protease inhibittor, active against genotype $1(1 \mathrm{~b}>1 \mathrm{a})$. [4] The efficacy of simeprevir has been evaluated in several open label and controlled trials of both treatment-naïve and treatment-experienced patients with chronic HCV genotype 1 infection. $[4,5,8]$ Addition of simeprevir to peg-IFN/ribavirin or to sofosbuvir produced significantly higher SVR rates compared to placebo or historic controls in all of the trials. [4, 5, 8] However, the efficacy of simeprevir was reduced in genotype 1a HCV infected patients who had the NS3 Q80K polymorphism at baseline (approximately one-third of US patients in the clinical studies). [4, 5, 8] Therefore, it is recommended that testing for Q80K be performed before treatment with simeprevir for treatment of $\mathrm{HCV}$ 1a genotype. Alternative therapy should be used for those who have it. [4, 8] The recommended dosage of simeprevir capsule is $150 \mathrm{mg}$ once daily with food. [8] Simeprevir is nearly entirely bound by plasma proteins and cleared by biliary excretion. Because there is no renal excretion, dose adjustments are not required in the presence of renal dysfunction. Simeprevir is a substrate and inhibitor of intestinal CYP3A and P-gp. [8] Simeprevir should not be administered with moderate or strong inhibitors or inducers of CYP3A. [8] Simeprevir is better tolerated then the first wave, first generation NS3/4A HCV protease inhibitors. Rash and photosensitivity (affecting quarter of recipients) and mild reversible isolated hyperbilirubinemia are the most common side effects. [8]

\section{Nucleotide analog inhibitor of the $\mathrm{HCV}$ NS5B RNA-dependent RNA polymerase}

\section{Sofosbuvir}

Sofosbuvir (Sovaldi) is a nucleotide ana$\log$ inhibitor of the HCV NS5B RNA-dependent RNA polymerase (RdRp). [4, 5, 9] Sofosbuvir is a prodrug that undergoes intracellular metabolism in the liver (phosphorylation) to form the pharmacologically active uridine ana- log triphosphate (GS-461203), which can be incorporated into newly synthesized RNA primer strand by the RdRp polymerase and acts as a chain terminator. $[4,9]$ It is pangenotypic in its anti-HCV activity and has a high barrier for resistance. [4, 9] Manufacturer is Gilead Sciences, which has co-formulated sofosbuvir with ledipasvir in fixed dose combination pill Harvoni. [9, 10] At the present time, sofosbuvir serves as a "backbone" for several of the DAAs treatment regimens. [3-5] It has been studied in combination with peg-IFN and RBV, and in IFN-free regimens with ribavirin, or with simprevir, or with daclatasivir or ledipasvir. [3-5, 9-12] The recommended dosage of sofosbuvir tablet is $400 \mathrm{mg}$ once daily without regard to food. [3, 9] Sofosbuvir is extensively metabolized in the liver to form the active metabolite GS-461203, and also the inactive metabolite GS-331007. [9]. Sofosbuvir is a substrate of drug transporter P-gp. Only clinically significant drug interaction is with drugs that are P-gp inducers in the intestine (e.g., rifampin or St. John's wort), which may decrease sofosbuvir plasma concentration and it's therapeutic effect, and thus concomitant use with sofosbuvir is not recommended. [9] Approximately $80 \%$ of sofusbuvir and its inactive metabolite (GS-331007) are excreted in the urine. [9] A 4-hour hemodialysis session removes approximately $18 \%$ of administered dose. No dosage adjustment is required for patients with mild or moderate renal impairment, but no dosage recommendation are given for patients with severe renal impairment or ESRD. [9] There is substantial accumulation of the sofosbuvir- inactive metabolite (GS-331007) in ESRD, with unclear clinical conesquence. [3, 9] Sofosbuvir is generally well tolerated with headache and malaise being the most common side effects in the clinical trials. [9] Post marketing surveillance elicited reports of serious symptomatic bradycardia when sofosbuvir (together with other DAAs) were co-administered with amiodarone. The onset was within days of commencing the HCV regimen. [13] The mechanism of this effect is unknown at this time but most of the patients had advanced liver disease (possibly leading to above-normal amiodarone levels) and were receiving beta-blockers [13]. The new labels of sofosbuvir -containing regimen state 
that coadministration of amiodarone with is not recommendded, but if coadministration is necessary, close cardiac monitoring is recommended for the first 2 weeks of starting DAAs. [13]

\section{Inhibitor of nonstructural protein 5A (NS5A)}

\section{Daclatasvir}

Daclatasvir (Daklinza) is an inhibitor of NS5A, a nonstructural protein encoded by HCV. Daclatasvir binds to the NS5A (palm domain 1 region of the protein) causing structural distortions that interfere with NS5A functions, inhibiting both viral RNA replication and virion assembly. [4, 12] Daclatasvir has activity against all genotypes, especially genotypes 1, 2, and 3, and lesser activity against genotypes 4, 5 and 6 . [12] It has a low barrier for resistance. [4] Cross resistance between daclatasvir and other NS5A inhibitors is expected. Cross-resistance between daclatasvir and other classes of directacting antivirals is not expected. [4] Daclatasvir is currently approved for use in Europe in combination with other anti-HCV agents for genotypes $1,2,3$, and 4 . It was approved in the USA in July 2015 for use with sofosbuvir for the treatment of chronic HCV genotype 3 infection. $[4,12]$. Manufacturer of daclatasvir, BristolMyers Squibb (BMS) is currently studying daclatasvir as a component of a fixed-dose combination pill (daclatasvir-asunaprevir-beclabuvir with or without ribavirin). [4] Daclatasvir is available as a $60 \mathrm{mg}$ tablet and $30 \mathrm{mg}$ tablet. The recommended dose of daclatasvir is $60 \mathrm{mg}$ orally once daily, without regard to food. [12] Daclatasvir is a substrate of CYP3A4, and moderate inhibitor of P-gp. [12] Daclatasvir use is contraindicated in combination with drugs that strongly induce CYP3A (phenytoin, carbamazepine, rifampin, and St. John's wort etc.), which may lead to lower exposure and loss of efficacy of daclatasvir. [12] Dose adjustments for daclatasvir in patients receiving strong inhibitors, and moderate inducers of CYP3A are predictable. This makes this drug very valuable in HIV-HCV co-infected patients receiving antiretroviral (anti-HIV) therapy or transplant recipients with $\mathrm{HCV}$ of the allograft. [3, 4, 12] When given concomitantly with a strong CYP3A inhibitor (clarithromycin, ritonavir, voriconazole etc.), the daclatasvir dose should be reduced to
$30 \mathrm{mg}$ once daily. $[3,12]$ When given with moderate cytochrome P-450 3A4 inducers (dexamethasone, efavirenz, etravirine etc.), the DCV dose should be increased to $90 \mathrm{mg}$ once daily. $[3,12]$ No dosage adjustment of daclatasvir is required for patients with any degree of hepatic impairment or renal impairment. [12] Daclatasvir is well tolerated, and most common adverse reactions $(\geq 10 \%)$ observed in combination with sofosbuvir were headache and fatigue. [12] Daclatasvir, as with any other DAAs when coadministered with sofosbuvir, and amiodarone may cause serious bradycardia. $[12,13]$

\section{Fixed dose formulations}

\section{Harvoni (ledipasvir / sofosbuvir)}

Sofosbuvir is a nucleotide analog inhibitor of the NS5B RNA-dependent RNA polymerase. Ledipasvir is an inhibitor of NS5A, a nonstructural protein encoded by HCV. It has potent activity against genotypes 1,4 , and 6 , but less activity against genotypes 2, 3 and 5. [4, 10]. It has a low barrier for resistance similar to the other first generation NS5A inhibittors. [4] Manufacturer is Gilead Sciences. Ledipasvir is not available as a stand-alone tablet, but is coformulated with sofosbuvir, in a fixed-dose combination pill called Harvoni. Each Harvoni tablet contains $90 \mathrm{mg}$ ledipasvir and $400 \mathrm{mg}$ sofosbuvir. [10] It is administered once daily, without regard to food. [10] It was FDA-approved in 2014 as the first peg-IFN and ribavirin-free single pill regimen to treat $\mathrm{CHC}$. Ledipasvir and sofosbuvir are substrates of drug transporters P-gp, and concomitant use with P-gp inducers (e.g., rifampin, carbamazepine or St. John's wort) is not recommended because it may lead to decreased ledipasvir and sofosbuvir plasma concentrations and lower therapeutic effect. [10] Additionally, ledipasvir absorption is significantly decreased with concurrent use of acid reducing agents. [10] It is recommended to separate antacid and Harvoni administration by 4 hours. Proton pump inhibitors (dose limited the equivalent of $20 \mathrm{mg}$ omeprazole) should not be taken before Harvoni but should be taken at the same time (simultaneously). [10] Coadministration of amiodarone with Harvoni may result in serious symptomatic bradycardia [10, 13]. Concurrent use simeprevir, which is a substrate and inhibitor of P-gp, and ledipasvir has been shown to 
increase serum concentrations of both drugs and is also not recommended. [10] Harvoni also increases serum concentrations of tenofovir, and may potentiate the nephrotoxicity of tenofovir disoproxil fumarate, especially with coadministered with other antiretroviral drugs that raise tenofovir levels (e.g., ritonavir-boosted HIV protease inhibitors). [10] For patients with mild, moderate, or severe hepatic impairment, no dosage adjustment is recommended, as is for patients with mild to moderate renal impairment. [10] However, there are no dose recommendations for patients with severe renal impairment (eGFR less than $30 \mathrm{ml} / \mathrm{min} / 1.73 \mathrm{~m}^{2}$ ) or end-stage renal disease (ESRD) requiring dialysis. [10] This is related to sofosbuvir, whose inactive metabolite accumulates in excess in patients with very decreased GFR. (See sofosbuvir for details). Harvoni is well tolerated with headache and malaise being the most common side effects. [10]

\section{Viekira Pak (USA); Holkira Pak \\ (Canada and other countries) \\ (paritaprevir/ritonavir/ombitasvir and dasabuvir)}

Viekira Pak (manufactured by Abbvie) is a 4-drug combination product that contains 3 DAAs (paritaprevir, ombitasvir and dasabuvir) with the pharmacologic enhancer ritonavir (used to increase the exposure of paritaprevir). [3, 4, 11] This regimen is also called "3D regimen", and resembles the treatment of HIV infection, where antiretroviral agents with different mechanisms of action are combined in order to increase efficacy and prevent evolution of resistance. Each DAA in Viekira Pak targets an $\mathrm{HCV}$ protein that is essential for viral replication. [11] Paritaprevir inhibits the HCV NS3/4A protease. Ombitasvir inhibits the NS5A protein. Dasabuvir is a non-nucleoside inhibitor of the HCV RNA-dependent RNA polymerase (NS5B protein). [11] Viekira Pak contains a fixed-dose combination of paritaprevir, ritonavir and ombitasvir in one tablet, and dasabuvir in a second tablet. It is administered 2 tablets (paritaprevir/ritonavir /ombitasvir 75/50/12.5 mg) once daily (in the morning) and 1 tablet dasabuvir $250 \mathrm{mg}$ - twice daily (morning and evening) with food. Viekera Pak is FDA approved for treatment of HCV genotype 1 infection. Abbvie also markets Technivie, which in essence is Viekera Pak without dasabuvir. It is FDA approved for treatment of genotype $4 \mathrm{HCV}$ infection together with ribavirin. Viekira Pak is well tolerated with fatigue, nausea, insomnia and skin reactions being the most common adverse effects. [11] Approximately 1\% of subjects receiving Viekira Pak in clinical trials, developed elevated alanine aminotransferase (ALT) $>5 \mathrm{x}$ upper limit of normal. The labeling carries a warning alerting patients and clinicians of the risk of ALT elevation and recommends ALT testing during the first four weeks of starting treatment, and as clinically indicated thereafter. [11] Viekira Pak is contraindicated in patients with severe hepatic impairment due to risk of potential toxicity. However, no renal dose adjustment is needed.

Viekira Pak, being a 4-drug combination has multiple drug interactions. Ritonavir as a strong CYP3A4 inhibitor will "boost" many drugs that are CYP3A4 substrates. Some drugs such as ergot alkaloids, lovastatin, simvastatin, pimozide, triazolam, and midazolam are contraindicated for use with Viekira Pak; some require dose reduction (e.g., cyclosporine and tacrolimus). Paritaprevir is CYP3A4 substrate and dasabuvir is CYP2C8 substrate. Viekira Pak is contraindicated with inducers of CYP2C8 or CYP3A4 or strong CYP3A4 inhibitors (e.g., rifampin, carbamazepine, rilpivirine, efaverenz, ritonavir-boosted darunavir or lopinavir, longacting inhaled beta-adrenoceptor agonist salmeterol). [3, 11] Clinicians should consult the labeling information and other resources (e.g., http://www.hep-druginteractions.org/) to ensure safety when prescribing this (and other DAA) regimens. [3, 11]

\section{Resistance to DAAs}

Evolution of resistance to DAAs is inevitable as is the case with any of the antimicrobial agents developed for clinical use. Risk factors for resistance to DAAs include suboptimal adherence to the medication regimen, pharmacokinetic interactions leading to lower blood levels of DAAs and advanced fibrosis. [3, 4] Clinical studies and real-world experience of using DAAs have revealed that resistant associated variants (RAVs) can be detected during on-treatment virologic breakthrough or after completion of treatment in persons with relapse 
of HCV infection. [3, 4] These RAVs are of particular clinical relevance for NS5A inhibitors and to lesser degree the NS3/4 protease inhibitors. [3, 4] The NS5A inhibitor RAVs are crossresistant to all of the approved agents in this class (daclatasvir, ledipasvir, and ombitasvir), and appear to persist for extended time. [4] Resistance testing is a useful tool in selecting the next treatment regimen in patients who experienced treatment failure using NS5A inhibitors and / or NS3/4 protease inhibitors and who urgently need to be treated (who can not await the approval of the next generation DAAs; e.g., patients with cirrhosis). [4] The commercially available assays test for RAVs to NS5A inhibitors and NS3/4 protease inhibitors. This recommendation is now available in the updated $\mathrm{HCV}$ treatment guideline [3]. Management of patients who have failed (relapsed after) DAA therapy is rapidly evolving, and current guidelines recommend treating such patients with different classes of DAAs based on the results of resistance testing (exception is sofosbuvir, which can be used in re-treatment regimen), for longer duration of time ( 24 weeks instead of 12 weeks) and with the addition of ribavirin. [3, 4]

\section{Select populations}

\section{HCV/HIV coinfection}

The World Health Organization estimates that there are 35 million people living with human immunodeficiency virus (HIV) globally, of whom approximately quarter or between 8 to 9 million have $\mathrm{HCV}$ co-infection. [3, 4, 15] Compared to HCV monoinfected, persons with $\mathrm{HCV} / \mathrm{HIV}$ coinfection have a higher rate of HCV persistence, higher HCV RNA levels, and faster progression to cirrhosis and end-stage liver disease. [4, 15] Liver failure is a now the major cause of death in the HIV-HCV coinfected persons. [3, 4, 15] Persons coinfected with HIV/HCV also had lower responses to peg-IFN and RBV than those with $\mathrm{HCV}$ monoinfection, in part related to the higher baseline HCV RNA levels. [4, 15] In the past, many clinical trials for HCV therapies have excluded HIV infected persons, for various reasons including lack of data in this population, perceived high risk for relapse, non-response and drug interactions. [15] Several recent studies with DAAs have demonstrated that SVR rates are remarkably similar in the HIV co-infected compared to HCV monoinfected patients treated with the same regimen for the same HCV genotype. [3, 4, 15] Thus, the treatment recommendations for $\mathrm{HIV} / \mathrm{HCV}$ coinfected persons are the same as for those with HCV monoinfection, with consideration of potential drug-drug interactions with HIV medications. $[3,15]$

\section{HBV/HCV coinfection}

The individuals with hepatitis B virus (HBV) and HCV co-infection are at very high risk of hepatic cirrhosis and hepatocellular carcinoma, making this population a priority for treatment with DAAs. [3, 14] Current HCV treatment guidelines do not provide detailed guidance on management of of such patients. [3, 14] This in part is related to lack of data for this population, related to exclusion of these patients from the clinical trials of DAAs. [14] $\mathrm{HCV}$ is known to cause suppression of HBV replication in coinfected patients, and increased HBV replication following successful treatment of $\mathrm{HCV}$ with peg-IFN and ribavirin has been reported. [14] Recent reports show that HBV "flare" (HBV reactivation and severe hepatitis) occurs with the use of DAAs. [14] This risk is underappreciated, but appears to be greater with DAA regimens compared to peg-IFN, in light of their increased potency of DAAs against $\mathrm{HCV}$ and lack of anti-HBV activity. [14]. One proposed management strategy to prevent $\mathrm{HBV}$ "flare" in these patients include regular monitorring of HBVDNA prior and during DAA therapy (every 2 to 4 weeks), and providing HBV therapy when HBV DNA levels become detectable or increase from their previous baseline. [14] In addition, all patients starting DAAs should be assessed for presence of hepatitis B coinfection (HBsAg, anti-HBc, and anti-HBs), and should receive HBV vaccine if susceptible. [14]

\section{Approach to treating HCV infected patient}

Once chronic hepatitis $\mathrm{C}$ infection has been confirmed, the clinician should perform a thorough history and physical examination focusing on risk factors for infection, medical comorbidities, extra-hepatic HCV manifestations and looking for signs of advanced liver disease. Baseline laboratory tests include liver function tests (LFT), INR, complete blood counts (CBC), 
renal function tests including eGFR, assays to detect HIV and HBV coinfection, blood HCV RNA level, and HCV genotype and subtype. [3] Staging of liver fibrosis is recommended to determine the urgency for treatment, to screen for complications of cirrhosis such as esophageal varices and hepatocellular carcinoma, and occasionally to satisfy the payer (USA heath insurance) requirement. This can be accomplished by certain biomarkers (e.g., FibroSure), imaging modalities (MRI, ultrasound), transient elastography (FibroScan) and liver biopsy. The patients should be advised on hepatoprotective measures, including avoidance of hepatotoxins, weight reduction if obese, and immunizations against hepatitis A and B. Assessment of potential drug-drug interactions with concomitant medications and counseling regarding the importance of adherence are recommended prior to starting $\mathrm{HCV}$ therapy. Upon starting treatment, "safety" labs (LFTs, eGFR, CBC) should be done at 4 week and as needed there after. Quantitative HCV viral load testing is recommended after 4 weeks of therapy, end of therapy and at 12 weeks following completion of therapy. [3] Patients with advanced fibrosis or cirrhosis should undergo ultrasound testing every 6 months as surveillance for hepatocellular carcinoma, and endoscopic surveillance for esophageal varices (if cirrhotic). [3]. Serum pregnancy testing is recommended for women of childbearing age prior to beginning treatment, especially if the regimen includes ribavirin. [3]

\section{Cost of DAA regimens}

Cost of the DAA regimens for treatmentnaive and treatment-experienced $\mathrm{HCV}$ infected non-cirrhotic and cirrhotic patients in the USA ranges from approximately $\$ 63,000$ to $\$ 300,000$. $[3,16]$ The common answer to the high price of DAAs by the various payers (insurers) has been to restrict the access to therapy, usually based on the severity of liver disease. [3, 4, 16]. However the rationing of DAAs has a different flavor when compared to other rationing decisions in healthcare, such as organ transplanttation, where supply is limited. [16] Rationing DAAs in the USA represents a decision to allocate finite healthcare dollars to corporate profiteering instead of curing patients. [16] The very high cost of the DAAs is a major obstacle to its widespread use at this time and may lead to downfall of $\mathrm{HCV}$ elimination strategies. [4, 16]

\section{Conclusion}

In the past 2 years, the approval of several DAAs has dramatically changed the management of patients with chronic HCV infection [3-15]. HCV can now be cured in over $90 \%$ of patients, using a well-tolerated oral therapy with low pill burden and short treatment duration. Ongoing challenges include treatment of select populations (e.g., patients with end-stage renal disease and decompensated cirrhosis), cost of the medications and access of care, and increasing resistance to DAAs. Fortunately, the HCV therapeutic pipeline is rich and more DAAs are expected to be approved over the next years, including pangenotypic dual- and triple-DAA regimens, with higher barriers for resistance, that produce SVR rates over $95 \%$ after a treatment duration of less then 8 weeks, and are well tolerated in all populations and may not require dose adjustment for renal or hepatic failure.

\section{REFERENCES}

1. Hepatitis C. WHO. Available at:

www.who.int/mediacentre/factsheets/fs164/en/. Accessed October 1, 2015.

2. SC Rey and DL Thomas. "Hepatitis C" (Chapter 156). In Mandell, Douglas, and Bennett's principles and practice of infectious diseases, edited by JE Bennett, R Dolin, MJ Blaser. Philadelphia: Elsevier, 2015.

3. American Association for the Study of Liver Diseases/Infectious Diseases Society of America/International Antiviral Society-USA. HCV Guidance: Recommendations for testing, managing, and treating hepatitis C. Available at:

www.hcvguidelines.org. Accessed October 1, 2015.

4. JM Pawlotsky et al. From non-A, non-B hepatitis to hepatitis C virus cure. J Hepatol. 2015; 62: S87.

5. EASL Recommendations on treatment of Hepatitis C 2015. J Hepatol 2015; 63: 199..

6. Telaprevir (Incivek) and Boceprevir (Victrelis) for Chronic Hepatitis C. Med Lett Drugs Ther. 2011; 53: 57.

7. Drugs for Hepatitis C. Med Lett Drugs Ther. 2012; 54: 81.

8. Simeprevir (Olysio) for Chronic Hepatitis C. Med Lett Drugs Ther. 2014; 56: 1.

9. Sofosbuvir (Sovaldi) for chronic hepatitis C. Med Lett Drugs Ther. 2014; 56: 5.

10. A Combination of Ledipasvir and Sofosbuvir (Harvoni) for Hepatitis C. Med Lett Drugs Ther. 2014; 56: 112

11. A 4-Drug Combination (Viekira Pak) for Hepatitis C. Med Lett Drugs Ther. 2015; 57: 15.

12. Daclatasvir (Daklinza) for HCV Genotype 3 Infection. Med Lett Drugs Ther. 2015; 57: 142.

13. In brief: severe bradycardia with sofosbuvir and amiodarone. Med Lett Drugs Ther. 2015; 57: 58.

14. JM Collins et al. Hepatitis B virus reactivation during successful treatment of hepatitis $\mathrm{C}$ virus with sofosbuvir and simeprevir. Clin Infect Dis. 2015; 61: 1304. 
15. SD Safran. HIV coinfected have similar SVR rates as HCV monoinfected with DAAs: It's time to end segregation and integrate $\mathrm{HIV}$ patients into $\mathrm{HCV}$ trials. Clin Infect Dis. 2015; 61: 1127.

16. SB Trooskin et al. Access to costly new hepatitis C drugs: medicine, money, and advocacy. Clin Infect Dis (2015) doi: 10.1093/cid/civ677 (First published online: August 12, 2015)

Резиме

\section{НОВИ ТЕРАПИИ ЗА ВИРУСОТ ХЕПАТИТИС Ц}

\section{Хари Поленаковиќ, FACP, FIDSA}

Вонреден професор по интерна медицина на Универзитетот Wright State,

Медицински факултет Boonshoft; инфектолог, медицински директор на Одделот за епидемиологија, болница Miami Valley; заменик-директор, Програма за адултна муковисцидоза, Детска болница во Дејтон

Вирусот на хепатитис Ц (ХЦВ), главен етиолошки агенс на „,non-A, non-hepatitis B“, е откриен пред 26 години. Уште пред неговото откритие, интерферон- $\alpha$ (ИФН) беше користен за лекување на оваа инфекција. Во следните две децении видовме серија постепени подобрувања на ИФН-терапиите, од продолжување на времетраењето на терапијата, користење ИФН во комбинација со орален рибавирин, употребување пегилиран ИФН со рибавирин, а од неодамна додавање орални соединенија што ја инхибираат репликацијата на ХЦВ (директно дејствувачки антивирусни лекови - ДАА). ДАА блокираат одредени фази во животниот циклус на ХЦВ и сега се користат во комбинација за лекување ХЦВ-инфекција, без потреба на ИФН. Комбинацијата на овие орални ДАА е многу ефикасна, има минимални несакани дејства и се зема за релативно краток период. Одобрените ДАА може да излечат повеќе од $90 \%$ од лицата со хронична ХЦВ инфекција, со што се намалува ризикот од смрт предизвикана од цироза и хепатоцелуларен карцином. Сепак, овие лекови се многу скапи и моментно нивната превисока цена значително го ограничува пристапот на оваа терапија за многу пациенти заразени од ХЦВ.

Клучни зборови: хепатитис Ц, третман, директно дејствувачки антивирусни лекови 